Csaba András Dézsi, Dávid Fekete, Veronika Szentes, Tímea Laczkovits-Takács

\title{
Impact of the Coronavirus Epidemic on Local Social and Healthcare Services through the Example of a Hungarian City
}

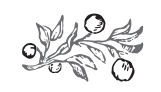

Summary

This paper analyses the impacts of the globally disruptive COVID-19 pandemic, and local responses to the above challenges, more specifically, the operation of services under the state of emergency through the example of Gyôr. With the outbreak of the pandemic, state and municipal stakeholders responsible for public service provision became the focus of public attention. Their capacity to provide quick, efficient and firm action in response to novel situations and challenges was constrained by the internal operational deficiencies of large care systems, notably, undersupply in human and financial resources and the absence of flexibility and speed in various domains of state and municipal administration. Experience shows that full compliance with government measures and regulations was indispensable for the elaboration of local responses and good practices. In Gyór, despite the municipality's reputation for the high standard operation of health and social care services in the framework of its mandatory and voluntary functions and the presence of advanced care systems,

Dr Csaba András DÉzsi university professor, Széchenyi István University, Department of Health Sciences (dcsa62@gmail.com), DÁvid FEkete assistant professor, Széchenyi István University Regional Science and Public Policy Department (fdavid@ sze.hu), Veronika Szentes, senior assistant, Aladár Petz University Teaching Hospital, Gyốr, Tímea Laczkovits-Takács PhD candidate, Széchenyi István University, Doctoral School of Regional and Economic Sciences (takacs.timea@sze.hu). 
Csaba András Dézsi, Dávid Fekete, Veronika Szentes, Tímea Laczkovits-Takács: Impact...

tremendous human resources were required to tackle the emergency situation. This paper provides a detailed discussion of the relevant locally implemented practices and measures.

Journal of Economic Literature (JEL) codes: O18, I18, H75, R50

Keywords: Coronavirus pandemic, city, local social welfare system, healthcare, housing, state of emergency

\section{INTRODUCTION}

Urban living is a unique and unparalleled way of life. The urban environment, our immediate surroundings exhibit distinctly urban features such as wide streets, tall buildings (historic buildings or modern constructions in new business districts), heavy car traffic, trams, buses, metro and large masses of people everywhere. Virtually everywhere: on public transport facilities, in theatres, cinemas, restaurants, places of entertainment and cultural events. But also in workplaces, schools and universities. Congestion is an inherent feature of urban life, resulting from the interaction of local residents and the crowds of tourists. This congestion, i.e. the co-presence of a large number of people offering an ideal context for the spread of the Coronavirus poses the greatest threat for us today. Despite a considerable amount of experiences acquired in the first wave on the transformative effects of the virus on everyday urban life, the difficulties faced by urban residents in the event of further waves of the pandemic, its disruptive effects on urban lifestyles can only be estimated. But how exactly were the cities affected?

First, congestion as a typically urban phenomenon disappeared almost instantly. Tourists were the first to flee. The imposed international restrictions and travel bans led to a cancelling of international flights, and tourism service providers in the cities closed their premises. Second, the introduced quarantine measures produced empty streets, barren public spaces, deserted university lecture halls and vacant auditoriums in our cities and large parts of Europe. With the imposition of home office, coffee shops and restaurants in business districts lost their customer base and cultural stakeholders had to suspend their activities. The generalisation of home office was observed in previously unimaginable areas. As a result of the relocation of work to home, commuting to cities was eliminated. Third, in addition to the disappearance of incoming commuters, the physical absence of local workers from business districts left entire neighbourhoods vacant. All this has significantly reduced or eliminated inbound foreign and domestic arrivals and intra-urban movements in cities. In sum, the Coronavirus situation has deprived cities of one of their main attributes, congestion.

The Coronavirus pandemic also exposed the vulnerability of social and healthcare systems in the affected cities. In response to the human pandemic causing a mass illness and endangering the safety of life and property, the Hungarian Government de- 
Civic Review · Vol. 16, Special Issue, 2020

clared a state of emergency ${ }^{1}$ across the entire territory of Hungary on 11 March 2020 starting from 3 p.m., which authorized the Government to adopt exceptional measures, suspend the application of certain acts and derogate from the provisions of laws, pursuant to the relevant provisions of the Fundamental Law. ${ }^{2}$ Government decrees issued during the state of emergency were to remain in force for a period of 15 days, and their extension required the authorisation of the National Assembly, as stated in the Act on the Protection against the Coronavirus entering into force on $30 \mathrm{March}$, 2020. The law on the elimination of the emergency situation due to the Coronavirus pandemic was passed by the Parliament on 16 June, 2020 and entered into force as of midnight on 17 June 2020.

This paper presents a case study analysis of COVID-related measures implemented by a Hungarian city in the domain of social policy and primary healthcare. The City of Gyôr with its 130,000 permanent residents is the 5th most populous city in Hungary (in addition to the capital), and including its immediate catchment area, the city provides services for a total of 200-250 thousand people. Györ hosts the largest engine factory of the world as well as Audi's major vehicle factory. The city is one of the most important economic centres in Hungary.

Service delivery within the framework of the human service model of Gyor and the model's specifics has been the subject of a number of research endeavours. A recent research study analyses the human service model of Győr, focusing on healthcare service delivery (Laczkovits-Takács, 2018a). A separate paper investigates the evolution and role of social policy in Gyór based on a review of strategic urban development documents (Laczkovits-Takács, 2019c) and the role of the Municipality of Gyôr in social public service delivery (Laczkovits-Takács, 2019a). The Healthy Cities Project pillar of the Gyôr human service model has also moved into the focus of academic attention lately (Laczkovits-Takács, 2018b; Laczkovits-Takács, 2019b; Laczkovits-Takács, 2019d). Another research focusing on social urban rehabilitation in Gyôr analyses a specific segment of the housing pillar of the Gyôr model (Fekete and Laczkovits-Takács, 2019).

\section{THE SOCIAL WELFARE SYSTEM AND THE CORONAVIRUS PANDEMIC}

The declaration of the state of emergency generated a number of tasks and a significant burden for the healthcare and social care systems. The operation of institutions and service providers, the key operating principles and procedures relating to health and social care were specified in Government decrees, the Ministry of Human Capacities (EMMI) orders, prospectuses, letters of the Minister of Human Capacities, implying a central prescription of rules and regulations and their local elaboration and implementation. Operational specifics were thus fixed by the central and local levels jointly. In the realm of local decision-making, pursuant to the relevant legislation ${ }^{3}$, as of 11 March 2020 the functions and competences of municipal councils, including powers delegated to committees, more specifically, the Committee for Social Affairs, Healthcare and Housing (hereinafter: SZELBI), were transferred to mayors under the state of danger. The last meeting of SZELBI took place on 16 March 2020 (SZELBI, 2020). 
Csaba András Dézsi, Dávid Fekete, Veronika Szentes, Tímea Laczkovits-Takács: Impact...

\section{Social assistance}

Caregiving for seniors over the age of 70

Under the state of emergency, protection and caregiving for the elderly were transferred into the competence of municipal social policy. Pursuant to the relevant provision of Government Decree 46/2020 (III.16), ${ }^{4}$ any person above the age of 70 who undertakes not to leave his/her place of residence or stay and notifies the local government thereof, is entitled to caregiving services provided the mayor of the local authority. In the field of caregiving for the elderly, the municipality provided the following forms of assistance:

- daily delivery of hot meals within the system of (fee-based) social care provision,

- purchase of alimentary products on a weekly basis,

- redeeming prescriptions on a weekly basis or according to demand (monthly prescriptions).

People over the age of 70 were requested to provide information to the local authority on their demand for care in either of the following forms (Gyór.hu, 2020a):

- personal submission of the completed declaration form downloaded from the www.gyor.hu website,

- sending the form via email,

- by phone.

While the needs reported through the above-specified communication channels were recorded by the staff of the Mayor's Office, the provision of caregiving for the elderly in Gyór was ensured by the staff of the United Health and Social Institution (hereinafter: EESZI), based on a preliminary request of the service in the above indicated forms (Gyórplusz.hu, 2020g). The performance of surplus tasks generated by the emergency did not require staff expansion in the EESZI. The employees of care centres took care of the administrative aspects of catering, while meal delivery was handled by the contracted partner. A separate group was established within the institutional boundaries of EESZI with employees recruited from members of senior clubs, school nurses, vehicle drivers of the Technical Supply Organisation and the Economic Operations Centre. The number of staff required for service delivery was adjusted to evolving demand and continuously monitored. At the peak of demand, nearly 30 people had to be recruited. Later on, demand for assistance in postal cheque payments was also registered, provided by the local authority in cooperation with Magyar Posta Zrt., which took care of the real-time posting of cheques collected every three weeks at local post offices. Misszió Mentô Betegszállító és Szolgáltató Kft. offered support in municipal task delivery through a provision of weekly transport services for seniors seeking to handle their administrative affairs (e.g. banking).

On 17 March 2020, the municipality informed local residents through various channels about caregiving for the elderly above the age of 70 , and the first requests were registered by EESZI on 18 March 2020. In addition to the services contained in the official prospectus (daily hot meals, shopping, redeeming prescriptions), the 
municipality of Gyôr offered assistance to residents over 70 in postal cheque payments and banking transactions with the participation of additional partners. Table 1 illustrates the number of seniors requesting municipal assistance.

Table 1: Number of care recipients per service type (persons)

\begin{tabular}{l|c}
\hline & $\begin{array}{c}\text { Number of requesters } \\
\text { (persons) }\end{array}$ \\
\hline Requested lunch & 267 \\
\hline Requested only shopping & 127 \\
\hline Requested redemption of prescription & 43 \\
\hline Requested only postal cheque payment & 70 \\
\hline Requested shopping and redemption of prescription & 283 \\
\hline Requested shopping and postal cheque payment & 25 \\
\hline Requested redemption of prescription and postal cheque payment & 6 \\
\hline $\begin{array}{l}\text { Requested shopping, redemption of prescription and postal cheque } \\
\text { payment }\end{array}$ & 39 \\
\hline
\end{tabular}

Source: Authors' own elaboration based on data from the United Health and Social Institution of Gyôr

\section{Social assistance}

Assistance is a high-priority field within the social sector, which, according to our data analysis, did not show significant disparities in terms of the number of submitted claims compared to previous years, as illustrated by Table 2. In the field of social assistance, apart from the postponement of the preparation of the environmental study, procedures were conducted as usual. The applications for assistance under the emergency situation did not outnumber relevant claims for the same period of the preceding year, while new groups, such as people who lost their jobs as well as workers unable to execute their job due to the emergency situation emerged among the applicants. During the period of emergency, the mayor evaluated a total of 280 applications for extraordinary settlement support in place of SZELBI (Decision 10/17/06/2020 of the Financial Ministry).

\section{Social services and primary child welfare services}

The municipality of Gyôr delivers various forms of personalised care services within the framework of the following institutions and the participation of civil partners with supply contracts:

- Unified Institute for Health and Social Care,

- Unified Nursery Institutional Network,

- Family and Child Welfare Centre,

- Homeless Assistance Service. 
Csaba András Dézsi, Dávid Fekete, Veronika Szentes, Tímea Laczkovits-Takács: Impact...

Table 2: Social assistance by the local government between March and May, 2019 and 2020 (persons)

\begin{tabular}{l|c|c|c|c|c|c}
\hline & \multicolumn{3}{|c|}{2019} & \multicolumn{3}{c}{2020} \\
\cline { 2 - 7 } & March & April & May & March & April & May \\
\hline Extraordinary settlement support & 79 & 77 & 78 & 73 & 89 & 81 \\
\hline Regular Child Protection Discount & 23 & 21 & 22 & 16 & 22 & 14 \\
\hline Housing aid & 47 & 37 & 49 & 49 & 39 & 52 \\
\hline Medication support & 24 & 23 & 29 & 21 & 27 & 26 \\
\hline Educational support & 0 & 0 & 0 & 0 & 0 & 0 \\
\hline Debt management & 0 & 0 & 0 & 0 & 0 & 0 \\
\hline
\end{tabular}

Source: Authors' own elaboration based on data from the Department of Social Welfare of the Mayor's Office of Gyôr

\section{Care for the elderly}

In the case of various forms of social assistance, a Government Decree ${ }^{5}$ ordered the cessation of service delivery and an entry ban for day care facilities (except for employees). This implied a suspension of the operation of senior clubs providing day care in Gyór.

A ban on visits imposed in residential institutions and temporary care homes starting with 8 March 2020, and the ensuing curfew from 15 March affected senior residents of 232 residential homes and 43 temporary care homes in Györ. EESZI no longer filled vacancies or accepted new resident applications. Infection control, and prevention tasks in particular, were adjusted to the crisis situation triggered by the Coronavirus pandemic in the institution's residential and temporary care homes, and a sufficient number of isolation rooms were prepared to quarantine the elderly in case of demand (Gyórplusz.hu, 2020h). Based on a decision ${ }^{6}$ of the National Chief Medical Officer, the ban on visits to residential homes was partially lifted from 8 June, 2020, and visits were allowed following preliminary telephone consultation with staff members of the mental health group or a designated nurse and subjected to strict rules (EESZI, 2020).

\section{Nursery care}

A locally adopted measure suspended nursery care in institutions operated by the municipality, churches and foundations as of 16 March, 2020. During this period, child supervision services offered by the municipality were accessible only for those unable to provide childcare under the following conditions (Gyórplusz.hu, 2020a):

- parents on maternity or paternal leave are banned from taking their nursery age children to the nursery community (presuming that they are able to provide childcare), 
- institutions are prohibited from accommodating children whose parents or relatives living in the same household were staying abroad in the past two weeks,

- a sick child with fever or sharing the same household with a person with fever shall not attend the nursery, and if he/she does, employees of the institution have to make sure that the child is immediately sent home.

The municipality, in order to ensure the organisation of service provision, requested a declaration from parents stating their demand for nursery service in the days to come. The declaration form could be accessed from the city's website, and the completed form was to be sent to the institution by e-mail or delivered in person.

Under the normal state of affairs, the 12 nurseries of Gyór provide day-care for 594 children. Between 16 March and 30 April, on average 3 to 12 children demanded nursery day-care, supplied by one or two groups of a nursery, respectively. A significant increase was observed from 11 May, when 10 groups of two nursery facilities ensured child supervision (Table 3).

Table 3: The number of children and groups in the care of the Györ nurseries between 16 March and 22 May 2020

\begin{tabular}{l|c|c|c|c|c|c|c|c|c|c}
\hline & $\begin{array}{c}\text { Week } \\
\mathbf{1 2}\end{array}$ & $\begin{array}{c}\text { Week } \\
\mathbf{1 3}\end{array}$ & $\begin{array}{c}\text { Week } \\
\mathbf{1 4}\end{array}$ & $\begin{array}{c}\text { Week } \\
\mathbf{1 5}\end{array}$ & $\begin{array}{c}\text { Week } \\
\mathbf{1 6}\end{array}$ & $\begin{array}{c}\text { Week } \\
\mathbf{1 7}\end{array}$ & $\begin{array}{c}\text { Week } \\
\mathbf{1 8}\end{array}$ & $\begin{array}{c}\text { Week } \\
\mathbf{1 9}\end{array}$ & $\begin{array}{c}\text { Week } \\
\mathbf{2 0}\end{array}$ & $\begin{array}{c}\text { Week } \\
\mathbf{2 1}\end{array}$ \\
\hline $\begin{array}{l}\text { Number of children } \\
\text { (persons) }\end{array}$ & 12 & 3 & 4 & 5 & 6 & 9 & 12 & 19 & 39 & 59 \\
\hline Group number & 2 & 1 & 1 & 1 & 1 & 2 & 2 & 4 & 10 & 14 \\
\hline
\end{tabular}

Source: Authors' own elaboration based on data from the Institution Maintenance Department of the Mayor's Office of Gyôr

Nursery care was thus operated on an on-call basis. With the easing of restrictions imposed by the Coronavirus pandemic, parents increasingly returned to their workplaces, triggering a rising demand for nurseries and a concomitant extension of nurseries' supervisory capacities. This necessitated the opening of an increasing number of groups or entire institutions and an extension of education staff ensuring the supervision of children (Györplusz.hu, 2020j).

In accordance with the government decree, as of 25 May 2020, nurseries in Gyôr were allowed to restore their pre-emergency operation. The number of children benefiting from day-care is presented in Table 4, which reveals a continuously rising trend in comparison to the preceding period.

Family and child welfare services

Reduced customer service was organized in each regional division of the Family and Child Welfare Centre, with priority given to telephone and electronic contact forms. The provision of street social work was maintained, while family visits were restricted to crisis situations, serious degree of vulnerability or official requests (EMMI, 2020c). 
Csaba András Dézsi, Dávid Fekete, Veronika Szentes, Tímea Laczkovits-Takács: Impact...

Table 4: The number of children and groups in nurseries in Györ between 25 May and 12 June 2020

\begin{tabular}{l|c|c|c}
\hline & Week & Week & Week \\
$\mathbf{2 2}$ & $\mathbf{2 3}$ & $\mathbf{2 4}$ \\
\hline Number of children (persons) & 275 & 372 & 426 \\
\hline Number of groups & 49 & 48 & 51 \\
\hline
\end{tabular}

Source: Authors' own elaboration based on data from the Institution Maintenance Department of the Mayor's Office of Györ

Despite the state of emergency, alerts issued on child or adult crisis situations as well as those reported by guardianship offices were evaluated on a mandatory basis. In the case of administrative tasks extending beyond on-call time, home office was officially permitted. Kindergarten and elementary school support staff were prohibited from conducting work on site and in public institutions, hospital social counselling services were provided by telephone and via e-mail (permanent counselling was suspended in hospitals), and psychological counselling was handled through Skype. The changes did not affect the functioning of the child protection alert system; the toll-free number was fully operational, adjusted to the opening hours of Family Support offices. However, the organisation of groups, courses and programmes of the Sziget-Kék Community Space and the HÍD was interrupted. The prominent role of the Family and Child Welfare Centre within the city and the local system of social care is underlined by its ongoing capacity to maintain its operation in compliance with stringent regulations under the pandemic, as demonstrated by statistical data (Table 5-6) depicting the operation of the Basic Services Group and the Authority Group. The family helpers of the Basic Services Group perform the classic family support as well as the basic child protection tasks. Case managers belonging to the Authority Group provide support and coordinate activities related to child protection care, prior to and accompanying authority measures. The month of April saw the implementation of 11 temporary placements requiring urgent action, i.e. the immediate removal of children from their families due to the prevalence of life-threatening circumstances, an alarmingly high number, given the yearly average rate of 1 or 2 interventions per month. The impact of the pandemic period triggered a two-fold increase in the number of police interventions reported to the centre, mainly on family conflicts, abuse, and a rise in the number of drug abuse and attempted suicide cases by young people.

\section{Care for the homeless}

The Homeless Assistance Service provides care for the homeless population within the administrative boundaries of Györ, comprising the following: night shelter, temporary night shelter, soup-kitchen, social catering, day-care, temporary care, rehabilitation, nursing, assistance, primary healthcare, with each service operated at 90-100\% capacity utilisation during the pandemic period. The dominance of elderly people 
Civic Review · Vol. 16, Special Issue, 2020

Table 5: Customer turnover of the Basic Service Group (4 regional divisions) in March, April and May 2020

\begin{tabular}{l|c|c|c}
\hline & Adult claimants (capita) & Children at risk (capita) & Turnover (persons) \\
\hline March 2020 & 375 & 337 & 1,155 \\
\hline April 2020 & 523 & 343 & 993 \\
\hline May 2020 & 524 & 368 & 1,076 \\
\hline
\end{tabular}

Source: Authors' own compilation based on data from the Family and Child Welfare Centre

Table 6: Customer turnover of the Authority Group in March, April and May 2020

\begin{tabular}{l|c|c}
\hline & Children at risk (capita) & Turnover (capita) \\
\hline March 2020 & 458 & 617 \\
\hline April 2020 & 448 & 1,066 \\
\hline May 2020 & 435 & 905 \\
\hline
\end{tabular}

Source: Own compilation based on data from the Family and Child Welfare Centre

benefiting from care services of the institution in the Homeless Shelter and the large number of elderly and sick residents of transitional shelters required the observation of rules applicable to residential institutions for elderly persons, in addition to those pertaining to homeless care. In parallel to the imposition of a ban on visits, a curfew was extended to the entire institution as of 9 March 2020, including a prohibition of visits by residents accommodated in various institutional departments. This was followed by the ordering of a partial curfew and a ban on new admissions starting with 18 March 2020. Leaving the institute's premises was prohibited, except in justified cases (work and medical examinations) and for legitimate reasons (the demise of a close relative), with the special permission of the head of the institution. In compliance with stringent local regulations and procedures, the provision of meals was confined to specified hours, conducted in isolated circumstances and supervised by a social worker. Medical care was supplied only in exceptional cases (blood sampling, bandaging), upon preliminary request, also attended by a social worker. Under the curfew, the institution's staff received extraordinary authorisation to purchase tobacco products and excise goods (lottery, sweets) twice a week, depending on residents' demands. Since the permanent internment of individuals diagnosed with a substance use disorder was a daunting task, a temporary relaxation of house rules was necessary to allow for residents a moderate consumption of alcoholic beverages under controlled circumstances. With regard to the homeless, the curfew was lifted on 8 June (NNK, 2020) and the ban on visits was revoked on 18 June (NNK, 2020).

After the first wave of the pandemic, the mayor of Gyôr distributed a reward funded from municipal resources to social workers who provided daily care for the needy. 230 employees of the United Health and Social Institution and 42 employees of the 
Csaba András Dézsi, Dávid Fekete, Veronika Szentes, Tímea Laczkovits-Takács: Impact...

Homeless Assistance Service (Győrplusz.hu, 2020) obtained a reward of HUF 110,000 (approx. EUR 315).

\section{HEALTHCARE SYSTEM}

The emergency period transformed the functioning of the system of primary healthcare as well. As of 16 March 2020, the provision of planned healthcare treatment was limited to cases of emergency, i.e. in the event of a risk to life or permanent damage to health (EMMI, 2020b). With the reorganisation of patient care, direct patient care provision was confined to physicians under the age of 65 , constraining 9 general paediatricians and 10 general practitioners to delivery by telemedicine in the specific case of Gyôr. In accordance with the legislative changes, the following "new" opportunities were emphasized in patient care with a view on mitigating the risk of infection:

- assessment of suspected COVID-19 infections reported by phone,

- teleconsultation by phone,

- e-prescription.

In case of demand for general medical or paediatric care, first, the patient had to reserve an appointment by phone, and was entitled to medical examination at the physician's office only if deemed necessary by the GP. Remote consultation was prioritized, which proved to be sufficient in $90 \%$ of cases in Györ (Györplusz.hu, 2020d). Under the emergency, the use of e-prescription in primary healthcare enabled the automation of prescriptions instead of using handwritten notes. Hence, redemption of a patient's medication became possible for anyone presenting the patient's social security number and a credible proof of their identity. ${ }^{7}$

The operation of clinical nursing also followed the protocols tailored to the emergency situation, suspending personal consultations as a basic rule except in specific cases (new-born infants, persons who have recently given birth or whose life is in danger). Accordingly, nurses prioritized electronic forms of communication, such as telephone, e-mail, chat, video calls and skype. In the area of pregnant care, however, the cancellation of prescribed personal consultations was not possible (EMMI, 2020a).

In the primary dental care system, service provision under the state of emergency was limited to emergency care as of 15 March 2020. The operation of dental service organized within the framework of EESZI was maintained in the pandemic period, strictly confined to emergency dental interventions.

The delivery of general practitioner or paediatric on-call services also required prior consultation by phone, allowing patients to personally consult their physician only in cases of emergency. The patient turnover of on-call services in the pandemic period is illustrated by Table 7 , showing a significant decrease compared to the same months of the preceding year.

Besides primary healthcare delivery, the municipality assumed further duties as well. A toll-free emergency number was set up in Gyôr, which residents with concerns about their health and seeking advice could call (Gyôr.hu, 2020b). To operate the emergency number, the city donated 5 telephone sets for receiving calls round-the- 
Civic Review · Vol. 16, Special Issue, 2020

Table 7: Patient turnover at the Gyór General Practitioner Services in the months between March and June in 2019 and 2020

\begin{tabular}{l|c|c|c|c}
\hline & \multicolumn{2}{|c|}{2019} & \multicolumn{2}{c}{2020} \\
\hline & Adult (persons) & Children (persons) & Adult (persons) & Children (persons) \\
\hline March & 716 & 750 & 550 & 511 \\
\hline April & 736 & 634 & 285 & 103 \\
\hline May & 582 & 551 & 321 & 82 \\
\hline June & 780 & 856 & 324 & 181 \\
\hline
\end{tabular}

Source: Authors' own compilation based on the data provided by the Gyôr General Practitioners' Services Nonprofit Ltd.

clock. The line was operated by experienced medical practitioners working in 4-hour shifts, who provided information and advice to callers (Gyôrplusz.hu, 2020e). The creation of the line, in service since 19 March 2020, was intended to discharge the workload of healthcare institutions and workers. From 26 March, another emergency number was made accessible for parents in Gyór, operated by paediatricians ready to answer phone calls round the clock on issues related to the Coronavirus pandemic (Györplusz.hu, 2020f). The emergency number created for adults was called by 658 people, while the emergency number set up for parents was called by 56 people.

\section{LOCAL COLLABORATION, DONATIONS}

As a result of the collaboration of local actors, an epidemiological observatory was opened on 23 March 2020 in one of the dormitory buildings of Széchenyi István University. The aim of the established healthcare institution is to isolate suspected cases of Coronavirus that do not require hospitalisation and to monitor confirmed cases located in healthcare service areas of the Petz Hospital's Department of Infectious Diseases (Gyôrplusz. hu, 2020b). Individuals suspected to be infected with Coronavirus under the age of 65 and showing no severe symptoms were entitled to hospitalisation in the observatory. The centre provided medical care 24 hours a day with the assistance of one physician, four skilled health workers, and an administrator until 8 p.m. on 14 May 2020.

The hospital's foundation procured a molecular genetic testing device capable of detecting the Coronavirus, and municipal funding enabled the purchase of 2,000 test strips in addition to the 1,000 procured by the hospital. At the beginning of May 2020, Gyôr receieved another larger-capacity machine, financed by the State Healthcare Centre. Thanks to the machines, COVID tests were no longer sent to Budapest but performed locally and screening social care workers in Gyốr became possible (Györplusz.hu, 2020i).

On 20 March 2020, a few days after the declaration of emergency, the mayor of Györ, in collaboration with local stakeholders, established the Györ Emergency Fund to support the fight against the Coronavirus in Gyôr (Gyôrplusz.hu, 2020c). In the spirit of public interest commitment, a new account was opened, facilitating a reduction 
Csaba András Dézsi, Dávid Fekete, Veronika Szentes, Tímea Laczkovits-Takács: Impact...

of the tax base by support granted to economic organisations. As of 25 June 2020 , the fund had received 164 payments, totalling nearly HUF 54 million (approx. EUR 155,000). The smallest amount paid was HUF 1,000 (approx. EUR 3), while the largest was HUF 20 million (approx. EUR 57,150). The majority of subsidies allocated to the Gyór Emergency Fund were used for the purchase of medical equipment and protective clothing, significantly promoting the activities of the Petz Aladár County Teaching Hospital, and on twice occasions, quick tests were purchased for the hospital, and durable food was distributed to a hundred families in Gyór. The beneficiary families were selected on the basis of the recommendations of the Department of Social Welfare of the Mayor's Office and the Roma Minority Self-Government. The spectrum of material goods received by the municipality was very large - honey, several hundred kilograms of fruits, 20,000 pieces of chocolate, detergents, hand sanitizers, replacement sand for sandpits in playgrounds and institutions - which were donated to the city's public institutions. By courtesy of the Emergency Fund and Alcufer Kft., the hospital received 10,000 FFP2 protective masks, and through the contribution of Kardirex Health Centre, masks were distributed to 1,000 bus drivers in Győr.

\section{CONCLUSION}

The study gives an overview of the operation of human services in the City of Gyorr in an emergency situation. In an emergency, the social sector had to cope with a large number of additional tasks, such as caregiving for seniors over the age of 70, while the (reduced) operation of other fields in the sector was subject to stringent regulations adjusted to the changing circumstances and functions. Primary healthcare was also facing a daunting challenge due to the emergence of alternatives offered by telemedicine replacing previous practices of personalised care and its widespread utilisation in the treatment of patients. Experience demonstrates that operation under the state of emergency may generate a number of good practices whose incorporation into the daily routine of primary healthcare is worth considering. The mobilisation of urban stakeholders was highly efficient: the newly established Gyór Emergency Fund received significant donations, and a considerable amount of material goods were offered to those in need. During the first wave of the pandemic, the operators of urban care systems learnt to pursue their activities under extraordinary circumstances, and the current state of the pandemic suggests that the knowledge accumulated in spring 2020 will serve them well in the future.

\section{Notes}

\footnotetext{
Government Decree on the declaration of state of emergency 40/2020 (III. 11.).

Article 53 of the Hungarian Fundamental Law.

Act No. CXXVIII of 2011 concerning disaster management and amending certain related acts.

Government Decree 46/2020 (16 March) on the measures to be taken during the state of danger declared for the prevention of the human epidemic endangering life and property and causing massive disease outbreaks, for the elimination of its consequences, and for the protection of the health and lives of Hungarian citizens.
} 
Civic Review · Vol. 16, Special Issue, 2020

5 Decree No. 88/2020. (IV.5.) on measures to be implemented in the event of an emergency situation related to specific social and child protection services, and on rules of procedure of social services in a state of danger

6 Decision No. 13305-54/2020EÜIG of the National Chief Medical Officer.

7 Government Decree 8/2020. (II.12.) on the Amendment to Regulation No 44/2004 of the Minister for Health, Labour and Family Affairs on the prescription and dispensing of medicinal products for human use of 28 April 2004.

\section{REFERENCES}

EMMI (2020a): Az EMMI Egészségügyi Szakmai Kollégium Védônô (területi, iskolai, kórházi, családvédelem) Tagozat ajánlása a COVID-19 ellátásrenddel kapcsolatban [Recommendations by the board of regional, school, hospital and family care health visitors within the Board of Healthcare, Ministry of Health]. 21 March 2020.

EESZI (2020): Tájékoztató a bentlakásos otthonokban a látogatási tilalom részleges feloldásáról [Information on a partial lifting of the ban in care homes]. http://eeszi.hu.

EMMI (2020b): Azonnali intézkedések megtétele - miniszteri levél [Prompt actions. A letter from the minister]. 15 March 2020.

EMMI (2020c): Útmutató a koronavírus terjedésének megelôzésére és a kockázatok csökkentésére a család- és gyermekjóléti szolgáltatást nyújtók részére [Guide to the providers of family and child welfare service providers on the prevention of the spread of the Coronavirus and on reducing risks]. http:// szocialisportal.hu/documents/10181/242036/Utmutato_csalad_es_gyermekjoleti_szolgaltatok_reszere.pdf/57921alc-fe11-ff93-b306-8c2af82edf20.

Fekete, D. and Laczkovits-Takács, T. (2019a): The Effect of Social Rehabilitation on the Urban Segregations. Deturope, Vol. 11, No. 2, 143-168.

Fekete, D. and Laczkovits-Takács, T. (2019b): Gyôr-Újvárosi szociális városrehabilitációs program a gyôri humánszolgáltatási modell vonatkozásában [The social urban rehabilitation project of Gyôr-Újváros, with respect to the human services model of Gyôr]. In: Fekete, D. (ed.): Városfejlódés és agrárinnováció a Kárpát-medencében [Urban development and agricultural innovation in the Carpathian Basin]. Universitas-Gyôr Nonprofit Kft., Győr, 73-96.

Gyôr.hu (2020a): Maradjanak otthon a 70 éven felüliek [Stay at home over the age of 70]. Gyór.hu, https:// gyor.hu/maradjanak-otthon-a-70-even-feluliek/.

Győr.hu (2020b): Ingyenesen hívható zöldszám Győrben [Free emergency number in Győr]. Gyôr.hu, https://gyor.hu/ingyenesen-hivhato-zold-szam-gyorben/.

Gyôrplusz.hu (2020a): Új intézkedések Gyôrben [New measures in Gyôr]. Gyốrplusz.hu, www.gyorplusz.hu/ koronavirus/uj-intezkedesek-gyorben/.

Gyốrplusz.hu (2020b): Megfigyelóközpont lesz az egyetemen [Monitoring centre established at the university]. Gyôrplusz.hu, www.gyorplusz.hu/gyor/megfigyelo-kozpont-lesz-az-egyetemen/.

Gyôrplusz.hu (2020c): Létrejött a Gyôri Segélyalap [The Gyôr Emergency Fund established]. Gyôrplusz.hu, www.gyorplusz.hu/gyor/letrejott-a-gyori-segelyalap/.

Győrplusz.hu (2020d): Orvosi ellátás telefonon [Medical care by phone]. Gyốrplusz.hu, www.gyorplusz.hu/ gyor/orvosi-ellatas-telefonon/.

Gyôrplusz.hu (2020e): Sokan hívják az ingyenes gyôri zöld számot számot [Many call the free emergency number]. Gyôrplusz.hu, www.gyorplusz.hu/gyor/sokan-hivjak-a-gyori-zold-szamot/.

Gyôrplusz.hu (2020f): Gyermekorvosokat hívhatnak az új zöld számon [Pediatrists are accessible at the new emergency number]. Gyốrplusz.hu, www.gyorplusz.hu/gyor/ujabb-zold-szamot-hivhatnak-ingyenesen/.

Gyôrplusz.hu (2020g): Az EESZI akkor segít, ha elôtte kérik [EESZI helps if requested in advance]. Gyốrplusz.hu, www.gyorplusz.hu/gyor/az-eeszi-akkor-segit-ha-elotte-kerik/.

Gyốrplusz.hu (2020h): Az idôsek védelmében [In the protection of the elderly]. Gyốrplusz.hu, www.gyorplusz.hu/gyor/az-idosek-vedelmeben/. 
Csaba András Dézsi, Dávid Fekete, Veronika Szentes, Tímea Laczkovits-Takács: Impact...

Győrplusz.hu (2020i): Megérkezett a koronavírus-tesztet végzô berendezés [The Coronavirus testing apparatus has arrived]. Györplusz.hu, www.gyorplusz.hu/hirado/megerkezett-a-koronavirus-tesztet-vegzoberendezes/.

Gyôrplusz.hu (2020j): Újranyitnak hétfôn a bölcsôdék és az óvodák [Crèches and kindergartens to open on Monday]. Gyốrplusz.hu, www.gyorplusz.hu/gyor/hetfon-nyitnak-az-ovodak-es-bolcsodek/.

Győrplusz.hu (2020k): Elismerés a helytállásért [Acnowledgement for coping with the situation]. Györplusz. $h u$, www.gyorplusz.hu/gyor/elismeres-a-helytallasert/.

Laczkovits-Takács, T. (2018a): Gyôr humánszolgáltatási modelljének egészségügyi pillére 1990-tôl napjainkig [The health pillar of human services in the city of Győr from 1990 to date]. Polgári Szemle, Vol. 14, No. 1-3, 90-106, https://doi.org/10.24307/psz.2018.0808.

Laczkovits-Takács, T. (2018b): Vázlat a Gyôri Egészséges Városok Program idôsügyi intézkedéseirôl [Outline of the measures taken in the framework of the Healthy Cities Project of Gyôr in the interest of the elderly]. In: Fekete, D. and Filep, B. (eds.): Innováció, kultúra és életminôség a Kárpát-medence nagyvárosaiban [Innovation, culture and the quality of live in the cities of the Carpathian Basin]. Universitas-Gyôr Nonprofit Kft., Gyôr, 53-64.

Laczkovits-Takács, T. (2019a): Gyơr város önkormányzatának szerepvállalása a helyi szociális közszolgáltatások biztosításában [The role undertaken by the local government of Gyốr in ensuring local social public services]. Tér-Gazdaság-Ember, Vol. 7, No. 2-3, 277-309.

Laczkovits-Takács, T. (2019b): Idôsügy a gyôri Egészséges Városok Program tükrében [Elderly policy in the framework of the healthy cities project in Gyôr]. Polgári Szemle, Vol. 15, No. 1-3, 238-254, https://doi. org/10.24307/psz.2019.0915.

Laczkovits-Takács, T. (2019c): Győr stratégiai dokumentumai a szociálpolitika tükrében [The strategic documents of Gyôr in light of social policy]. Szociálpolitikai Szemle, Vol. 5, No. 1, 81-95.

Laczkovits-Takács, T. (2019d): Társadalmi részvétel és önkéntesség a győri Egészséges Városok Program keretein belül [Social participation and volunteering within the framework of the Healthy Cities Project, Győr]. In: Reisinger, A. et al. (eds.): Kulturális gazdaság [Cultural economy]. Conference paper, Széchenyi István University, Gyốr.

NNK (2020a): 13305-54/2020EÜIG ikt. sz. Országos Tisztifőorvosi Határozat [Resolution no. 1330554/2020EÜIG of the Chief Medical Officer]. National Public Health Center.

NNK (2020b): 13305-56/2020EÜIG ikt. sz. Országos Tisztifốorvosi Határozat [Resolution no. 1330556/2020EÜIG of the Chief Medical Officer]. National Public Health Center.

NNK (2020c): 13305-59/2020EÜIG ikt. sz. Országos Tisztifóorvosi Határozat [Resolution no. 1330559/2020EÜIG of the Chief Medical Officer]. National Public Health Center.

SZELBI (2020): Gyôr Megyei Jogú Város Önkormányzata Közgyúlésének Szociális, Egészségügyi és Lakásügyi Bizottsága - 4/2020. (III.16.) jegyzôkönyv [General Assembly of the Members of the Local Government of Gyôr, City of County Status, Committee for Social Affairs, Healthcare and Housing - Records no. 4/2020. (III.16.)]. 